\title{
Kearifan Lingkungan Masyarakat Dayak Benuaq dalam Novel Api Awan Asap: Kajian Ekokritik Giiford
}

\author{
Nina Queena Hadi Putria, ${ }^{1}$, Nisa Fitriyani Afifah b, 2, Hasrul Rahman c 3 \\ ab Universitas Mulawarman, Jalan Kuaro Gn. Kelua, Samarinda, Indonesia, 75119 \\ c Universitas Ahmad Dahlan, Jalan Kapas no. 9, DIY Yogyakarta, Indonesia, 55166 \\ ${ }^{1}$ ninaqueenahadiputri@gmail.com*; ${ }^{2}$ isafitriyanti5@gmail.com; ${ }^{3}$ rahmanhasrul12@gmail.com
}

\begin{tabular}{ll}
\hline INFO ARTIKEL & ABSTRAK \\
\hline Sejarah Artikel: & Penelitian ini bertujuan untuk mendeskripsikan lima nilai kearifan \\
Diterima: 03-07-2019 & lingkungan yang diturunkan dari kaidah estetika pastoral Giiford. Etstika \\
Direvisi: 02-10-2019 & Pastoral mendasari nilai kearifan lingkungan dalam sastra sebagai dasar \\
Disetujui: 02-10-2019 & kajian ekokritik sastra yang antroposentris, sehingga sastra tidak \\
& kehilangan fungsi kultural dan ekologisnya engenai landasan manusia \\
& dalam melestarikan alam berkaitan dengan sikap hormat, tanggung jawab, \\
Kata Kunci: & solidaritas, kasih saying dan kepedulian terhadap alam, serta tidak \\
ekokritik sastra & mengganggu kehidupan alam dalam novel Api Awan Asap karya (AAA) \\
kearifan lingkungan & Korrie Layun Rampan (KLR). Jenis Penelitian ini merupakan deskriptif \\
& kualititif dengan metode content analysis Harold D. Laswell yang bertujuan \\
& untuk mengetahui isi dan makna yang terkandung dalam data yang \\
& dianalisis dengan pembahasan secara mendalam terhadap isi dari \\
& informasi tertulis, dalam hal ini adalah novel $A A A$ yang ditulis sebagai \\
& jawaban terhadap isi kerusakan lingkungan yang disebabkan oleh \\
& masyarakat Dayak melalui pembakaran hutan. Kegiatan yang dilakukan \\
& adalah membaca, mencermati, menafsirkan, dan menganalisis novel $A A A$ \\
& karya KLR. Sumber data dalam penelitian ini adalah novel $A A A$ karya KLR \\
dan literatur yang relevan. Teknik pengumpulan data dilakukan dengan & teknik baca, teknik catat, dan teknik kajian kepustakaan. Hasil penelitian \\
dapat disimpulkan bahwa terdapat lima nilai kearifan lingkungan dalam \\
novel $A A A$ karya karya KLR.
\end{tabular}

\begin{tabular}{ll}
\hline Keywords: & ABSTRACT \\
ecocriticism & This study aims to describe the five values of wisdom environment that \\
giiford's aesthetics & derive from the rules of aesthetic pastoral Giiford. Etstika Pastoral \\
environmental wisdom & underlying value of the wisdom of ling-kungan in the literature as the basis \\
& for the study of ekokritik literature the anthropocentric, so the literature \\
does not lose the function of cultural and ecological around the foundation \\
of humans in preserving nature with regard to the attitude of respect, \\
responsibility, solidarity, compassion and concern for nature, as well as \\
not interfere with the natural life in the novel Api Awan Asap (AAA) Korrie \\
Layun Rampan (KLR). This Research type is descriptive kualititif with the \\
method of content analysis, Harold D. Laswell, which aims to determine \\
the content and meaning contained in the data are analyzed with a \\
discussion in depth of the contents of written information, in this case is a \\
novel AAA written as an answer to the contents to break the environment \\
caused by the Dayak community through the burning forest. The activities \\
carried out are read, observe, interpret, and analyze a novel AAA works \\
KLR. Data source in this research is a novel AAA works KLR and the \\
relevant literature. Data collection techniques done with the technique of \\
read, engineering record, and the techniques of literature review. The
\end{tabular}


results of the research can be concluded that there are five values the wisdom of the environment in the novel AAA works KLR.

\section{PENDAHULUAN}

Kerusakan lingkungan yang terjadi pada dasarnya melibatkan dua objek, yaitu objek manusia dan objek lingkungan. Sayangnya kerusakan ini tidak hanya terjadi diperkotaan, tetapi juga dipedesaan atau diperkampungan dengan latar belakang sosiologis masyarakat yang masih memegang tegus adat istiadat, pengelolaan hutan secara tradisional menyebabkan masyarakat asli menjadi kambing hitam atas kerusakan hutan yang merugikan masyarakat luas. Disatu sisi, masyarakat asli berusaha menjaga keseimbangan alam secara tradisional. Novel $A A A$ (Api Awan Asap) muncul sebagai jawaban atas tuduhan masyarakat luas yang menyatakan bahwa kebakaran dan kerusakan hutan tidak disebabkan oleh masyarakat Dayak, tetapi oleh masyarakat kota yang datang merambah hutan untuk kepentingan industri. Dalam hal ini, ekokritik Giffod merupakan kajian yang tepat mengenai nilai dan prinsip moral yang dianut oleh masyarakat tertentu sebagai pedoman dan kriteria dalam berperilaku sebagai manusia dengan kebiasaan hidup yang baik, diturunkan dan diwariskan melalui agama dan kebudayaan yang kumudian dianggap sebagai sumber utama dan nilai moral (Keraf dalam Sukmawan, 2016).

Rosyidah (2013) mengungkapkan bahwa ekokritisisme merupakan kajian terbaru dalam sastra yang berkembang sejak tahun 1990-an di Amerika dan Inggris. Ekokritisisme merupakan respon atas krisis lingkungan hidup yang terjadi sejak bergulirnya Revolusi Industri di Inggris pada abad ke-19. Awalnya, ekokritisisme mempertanyakan hubungan antara human (manusia) dengan non-human (lingkungan hidup) sebagaimana tercermin dalam banyak teks romantic dan nature writings. Seiring dengan perkembangannya, dikotomi antara human dan non-human menjadi semakin samar. Saat ini, kajian ekokritisisme tidak hanya terbatas pada teks-teks romantic dan nature writings, namun semua teks sastra dari semua periode dan tempat terutama dalam konteks keterkaitan antara teks, penulis, dan lingkungan secara keseluruhan (ekosfer).

Dalam kajian ekologi, manusia memiliki keterkaitan dengan lingkungan, keterkaitan tersebut terjalin dengan erat antara organisme dan lingkungan. Tanpa disadari, keadaan lingkungan alam mempunyai pengaruh terhadap kesastraan dan kebutuhan hidup manusia. Kajian ekologi sastra mempelajari tentang bagaimana manusia beradaptasi dengan lingkungan alam, hubungan antara kegiatan manusia, dan proses alam yang saling ketergantungan sebagai suatu komunitas alam. Harsono (dalam Setiawan, 2018) menyatakan bahwa ecocriticism berasal dari kata ecologydan criticism. Ekologi merupakan kajian ilmiah tentang pola hubungan tumbuh-tumbuhan, hewan, dan manusia terhadap satu sama lain dan terhadap lingkungannya. Kritik adalah bentuk dan ekspresi penilaian tentang kualitas baik atau buruk dari sesuatu. Dengan demikian, ekokritik dapat dipahami sebagai kritik berwawasan lingkungan. Masalah lingkungan memerlukan analisis budaya secara ilmiah karena masalah tersebut merupakan hasil interaksi antara pengetahuan ekologi dan perubahan budayanya (Juliasih, 2012)

Kajian sastra ini dapat membawa pesan kearifan lingkungan yang akan menjadi landasan bagi manusia dalam melestarikan alam (Sukmawan, 2016). Pembangunan besar-besaran, penebangan hutan, dan urbanisasi di Indonesia telah mempengaruhi lingkungan secara umum, yakni polusi udara, pencemaran sungai, pencemaran limbah industri dan pertanian, serta deforestasi (Dewi, 2015). Dengan begitu, pesan kearifan yang disampaikan melalui karya sastra dapat menjangkau keseluruhan 
di alam semesta sebagai upaya menyadarkan peran penting manusia pada lingkungan. Teori ekokritik mengolaborasi-kan antara sastra dan ekologi. Sastra berhubungan dengan hal yang bersifat imajinatif, namun sastra terkadang membahas realitas. Ekologi membahas mengenai atau isu-isu lingkungan, sosial, politik, maupun budaya (Juanda, 2018).

Novel Api Awan Asap (AAA) karya Korrie Layun Rampan (KLR) merupakan novel yang mengisahkan tentang kehidupan suku Dayak Benuaq di Kalimantan Timur yang menggambarkan idealnya sebuah peradaban dibangun dan bersinergi dengan alam yang harus senantiasa dijaga dan dilestarikan. Isi cerita dalam novel $A A A$ sangat berkaitan erat dengan kajian ekologi sastra, terutama tentang kearifan lingkungan di dalam kehidupan manusia. Hal ini sejalan dengan yang diungkapkan Iskandar (2001) bahwa masalah dalam kerusakan lingkungan di ekosistem hutan salah satunya ialah perladangan liar oleh penduduk pendatang (perilakunya yang sangat jauh berbeda dengan penduduk peladang asli, seperti masyarakat Baduy dan Dayak), kebakaran hutan dan lahan, untuk lahan transmigrasi dan perkebunan besar, serta pencurian hasil hutan, juga telah menyebabkan kerusakan ekosistem secara besar-besaran.

Banyak hal yang dapat dipelajari dari perilaku ramah lingkungan yang menjaga kelestarian sumber daya alam pada masyarakat lokal di Indonesia. Salah satunya adalah masyarakat lokal di pulau Kalimantan. Kalimantan sebagai pulau terbesar dan memiliki nutfah khas terutama yang ada di dalam hutan tropis di pulau ini yang juga menjadi penjaga ekosistem bumi di kawasan Asia. Sumber kayu yang melimpah dari hutan dan sumber emas dari sungai kini diambang kepunahan akibat eksploitasi pemegang konsesi hutan dan penambang berdampak pada deforestation dan menurunnya jumlah spesies hutan dan sungai, serta buruknya kualitas air. Potret perilaku tersebut berbeda dengan perilaku ekologis masyarakat asli yang tinggal dan hidup selama berabad-abad di sekitar hutan. Masyarakat lokal memiliki cara sendiri dalam memelihara tanah dan sumber daya alam lebih baik, karena mereka hidup di situ, menjadi saksi atas keberadaan alam tersebut. Nilai kearifan lokal telah membangun perilaku dalam menjaga lingkungan hutan lebih baik dari komunitas manapun (Hetti, 2015).

Kearifan lingkungan masih perlu diaplikasikan lagi di dalam kehidupan sehari-hari, terlebih dengan adanya orangorang yang masih belum paham akan pentingnya melestarikan alam. Penelitian ini bertujuan untuk mendeskripsikan Kearifan lingkungan dalam novel $A A A$ karya KLR dalam kajian ekologi sastra. Penelitian terhadap ekokritik sastra pada novel Api Awan Asap pernah dilakukan oleh Andri Erliansyah , Universitas Muhammadiyah Sumatera Utara tahun 2019 dengan judul Analisis Novel Api Awan Asap Karya Korrie Layun Rampan dengan Pendekatan Ekokritik. Hasil penelitian adalah mengetahui bagaimana pengarang menyampaikan bentuk kritik ekologi yang meliputi kritik terhadap lingkungan alam karena latar sosial budaya dalam novel Api Awan Asap karya Korrie Layun Rampan. Sedangankan pada penelitian ini lebih terfokus pada nilai kearifan lingkungan pada kaidah estetika pastoral Giiford yang meliputi a) telaah sikap hormat terhadap alam, b) sikap tanggung jawab terhadap alam, c) sikap solidaritas terhadap alam, d) sikap kasih sayang dan kepedulian terhadap alam, dan e) sikap tidak mengganggu kehidupan alam

\section{METODE}

Penelitian ini menggunakan metode kualitatif deskriptif, metode content analysis atau analisis isi untuk menelaah isi dari suatu dokumen. Metode content analysis Harold D. Laswell bertujuan untuk mengetahui isi dan makna yang terkandung dalam data yang dianalisis dengan pembahasan secara mendalam terhadap isi dari informasi tertulis, dalam hal ini adalah novel $A A A$ yang ditulis sebagai jawaban 
terhadap isi kerusakan lingkungan yang disebabkan oleh masyarakat Dayak melalui pembakaran hutan Sumber data dalam penelitian ini adalah: (1) teks, novel Api Awan Asap karya KLR; (2) buku-buku literatur yang relevan. Teknik pengumpulan data yang digunakan ialah teknik baca, teknik catat, dan teknik kajian kepustakaan. Metode yang digunakan adalah analisis data. Validitas data menggunakan triangulasi teori. Teknik analisis data yang digunakan dalam penelitian ini adalah teknik analisis Miles dan Hubermen (2007), yang terdiri atas redukasi data, penyajian data, dan penarikan kesimpulan atau verivikasi. Aktivitas ketiga komponen tersebut dilakukan secara interaktif dengan proses pengumpulan data.

\section{HASIL DAN PEMBAHASAN}

Novel AAA memiliki tema tentang kehidupan suku Dayak Benuaq yang masih sangat kental akan adat istiadat dan budayanya, serta mengisahkan bagaimana masyarakat Dayak tersebut memiliki kepedulian besar terhadap kondisi lingkungan alam di sekitarnya, seperti bagaimana warga desa Dempar memperlakukan alam dengan tidak semenamena, merawat dan menyelaraskan alam dengan cara yang baik dan hati-hati. Nilainilai tersebut akan dideskripsikan sebagai berikut.

\section{Kearifan Lingkungan}

Kearifan lingkungan merupakan nilai yang perlu diterapkan oleh manusia dalam pengelolaan dan pelestarian ekosistem/sumber daya alam di lingkungan sekitarnya. Di bawah ini merupakan hasil analisis yang penulis temukan tentang nilainilai kearifan lingkungan yang dipaparkan pada beberapa kutipan paragraf, sebagai berikut.

\section{Sikap Hormat Terhadap Alam}

Sikap hormat terhadap alam ini dimaksudkan bahwa alam mempunyai nilai pada dirinya sendiri, sehingga manusia perlu menghargai alam dan menyadari bahwa alam memiliki hak untuk dihormati. Sikap hormat terhadap alam ditunjukkan pada kutipan, sebagai berikut.

"Warga diajar membagi kawasan
tertentu untuk huma, kebun buah-
buahan yang kurang produktif dan
membagi kawasan tertentu untuk
tanaman produktifyang ekonomis. Cara
dan pola saya gabungkan di lou
Dempar ini, dan hasilnya bisa Anda
lihat sendiri. Semua kawasan tak ada
yang dijadikan lahan tidur. Semua
peruntukkan menghasilkan sesuai
dengan perkiraan yang ditentukan."
(Hal. 37, paragraf 1)

Sikap hormat terhadap alam ditunjukkan oleh warga desa Dempar yang sangat teliti dalam memperhatikan kawasankawasan yang akan dijadikan lahan. Dengan perlakuan yang tidak semena-mena, mereka mampu membuat lahan-lahan tersebut menghasilkan sesuatu yang mereka harapkan. Sikap tersebut dinilai sebagai sikap hormat yang dilakukannya terhadap alam karena mereka yakin bahwa alam tersebut memiliki nilai pada dirinya sehingga mereka harus selalu menghormati alam.

\section{Sikap Tanggung Jawab Moral Terhadap Alam}

Kutipan berikut terdapat nilai tanggung jawab moral pada diri manusia terhadap alam. Hal tersebut dapat ditunjukkan oleh manusia yang menyadari bahwa kelestarian alam merupakan tanggung jawab bersama seluruh umat manusia. Sehingga mereka berupaya untuk saling mengingatkan, melarang, dan menghukum siapa saja yang secara sengaja atau tidak membahayakan eksistensi alam.

"Jika salah seorang penghuni lou
mengakui bahwa pohon itu miliknya
dan mengambil buahnya untuk dijual?"
"Ada etika moral yang harus dipegang
teguh. Jika bagian yang telah
ditentukan sebagai milik bersama, 
harus diakui dan diterima seperti adat mengaturnya."

"Jadi, semua warga tunduk kepada adat?"

"Ya. Karena semua pelanggaran sekecil apa pun akan membuat warga itu merasa malu. Rasa malu itu tak dapat dibayar dengan uang, kecuali lewat penebusan upacara." (Hal. 32, paragraf 1)

Sikap tanggung jawab terhadap alam pada kutipan di atas dapat dilihat dari kesepakatan bersama yang telah dibuat oleh warga desa Dempar sebagai aturan dalam menjaga alam, dalam arti jika ada warga desa yang melanggar aturan tersebut, tidak segan-segan ia akan dihukum melalui upacara atas perbuatan yang telah dilakukannya, dan hal itu wajib dilaksanakan oleh pelaku.

"Pengusaha HPH dan HTI memang harus bertanggung jawab atas kerusakan lingkungan. Tapi siapa yang akan menuntut mereka?" (Hal. 104, paragraf 4)

Kutipan di atas memilki nilai sikap tanggung jawab moral terhadap alam yang ditunjukkan oleh sikap tidak terima yang dirasakan oleh warga desa Dempar terhadap para pengusaha yang telah merusak lingkungan sekitar desa dengan cara-cara yang tidak semestinya, seperti penebangan liar dan pembakaran hutan. Sehingga, warga ingin mengambil tindakan tegas agar mereka bertanggung jawab atas apa yang telah terjadi sesuai dengan aturan yang telah disepakati dalam menjaga dan merawat alam.

"Tetapi Pak...? Televisi telah menyiarkan kobaran api di beberapa kawasan di pulau kita. Jika misalnya api itu merembet kemari?"

"Kita padamkan bersama-sama."

"Ya, kita padamkan bersama-sama."

"Harus kita padamkan bersama-sama." (Hal. 115, paragraf 3)
Sikap tanggung jawab moral terhadap alam dari kutipan di atas dapat dilihat dari bagaimana warga desa Dempar saling bekerja sama atas apa yang telah terjadi pada lingkungan, dengan upaya memadamkan api yang membakar beberapa kawasan di sekitar desa. Hal tersebut menunjukkan bahwa mereka menyadari alam merupakan tanggung jawab mereka yang perlu ditindak secara bersama-sama.

"Dengan bersemangat para petinggi itu mengatakan akan mengambil tindakan tegas terhadap para pengusaha perkebunan, HTI, dan bahkan para peladang, jika tertangkap tangan melakukan pembakaran akan digiring ke kantor polisi sebelum segera menghadap meja hijau." (Hal. 129, paragraf 2)

Kutipan di atas termasuk dalam sikap tanggung jawab moral terhadap alam. Dapat dilihat ketika para petinggi akan mengambil tindakan tegas terhadap siapa pun yang berusaha merusak lingkungan sekitar dengan seenaknya. Karena jika hal tersebut terjadi, para pelaku akan diminta pertanggungjawaban sebagai balasan dengan apa yang telah dilakukannya.

"Kebun-kebun itu sebelumnya
merupakan bekas huma. Namun,
setelah ditanam tanaman keras,
lahannya jadi mati, dan tidak boleh lagi
digarap untuk huma. Pada lahan yang
terjangkau banjir warga menanam
rotan, enau, kedawung, petai, dan
pohon-pohon tanaman keras lainnya."
(Hal. 33, paragraf 4)

Kutipan di atas juga termasuk sikap tanggung jawab moral terhadap alam. Dapat dilihat bagaimana warga desa sangat taat pada larangan yang telah ada, dengan cara tidak akan melakukan penanaman di kawasan yang memang bukan tempatnya, dan akan menuruti aturan yang ada dengan cara menanam tanaman lahan di kawasan 
yang telah ditentukan. Hal tersebut dilakukan agar proses penanaman tidak semena-mena dilakukan.

\section{Sikap Solidaritas Terhadap Alam}

Sikap solidaritas terhadap alam merupakan pengakuan kedudukan sederajat dan setara dengan alam dan dengan sesama makhluk hidup, sikap tersebut diliputi dengan sikap untuk turut merasakan apa yang dirasakan oleh alam, sehingga manusia akan berupaya untuk menyelamatkannya. Sikap solidaritas terhadap alam ditunjukkan pada kutipan, sebagai berikut.

\section{"Orang di sini tak pernah merambah hutan dengan semena-mena. Seperti manusia, penduduk asli memandang tanah, akar, pohon, dan daun memiliki jiwa. Pohon-pohon di hutan boleh ditebang dan diambil sebatas kebutuhan warga. Tanah digarap seperlunya. Hewan diburu sebatas kebutuhan akan protein...." (Hal. 26, paragraf 8)}

Sikap solidaritas terhadap alam yang ditunjukkan pada kutipan di atas dapat dilihat dari bagaimana penduduk warga desa Dempar memandang tanaman dan hewan sebagai sesuatu yang memiliki kedudukan yang setara dengan mereka. Sehingga, mereka merasakan bahwa tanaman berhak untuk mereka jaga dan rawat, dengan cara tidak melakukan penebangan hutan dan penggarapan tanah semena-mena, serta tidak memburu hewan dengan seenaknya.

"Orang sini punya cara tertentu untuk menangkal bahaya kebakaran hutan. Jika mereka membakar ladang, mereka sudah tahu caranya agar api tidak menyebrang ke lahan lainnya. Nenek moyang telah mengajar mereka agar terhindar dari perusakan lingkungan hidup." (Hal. 35, paragraf 2)

Dari kutipan di atas sikap solidaritas terhadap alam, dapat dilihat dari bagaimana warga desa Dempar sangat berhati-hati dalam menjaga lingkungan sekitar agar tetap aman dari ancaman bahaya. Mereka melakukan dan selalu menerapkan cara-cara yang telah diajarkan dan diterapkan oleh nenek moyang dalam mencegah kerusakan lingkungan agar tidak terjadi.

\section{Sikap Kasih Sayang dan Kepedulian Terhadap Alam}

Sikap kasih sayang dan kepedulian terhadap alam dapat dicerminkan melalui sikap, ucapan, tindakan, dan perbuatan manusia kepada alam untuk tidak merusak, mengekploitasi, dan membawahkan alam, serta memberi perlindungan dan memelihara alam tanpa mengharapkan balasan. Sikap kasih sayang dan kepedulian terhadap alam ditunjukkan pada kutipan, sebagai berikut.

"Setahun yang lalu, Petinggi Jepi untuk pertama kalinya menginjak Jakarta. Menurut pakar Jakarta, ia telah melakukan sesuatu yang sangat bermanfaat bagi kelestarian lingkungan hidup. Desa Dempar yang dibangunnya belum mencapai usia dua puluh tahun, akan tetapi telah menampakkan tandatanda perkembangan yang mantap di masa depan." (Hal. 25, paragraf 1)

Sikap kasih sayang dan kepedulian terhadap alam pada kutipan di atas dapat dilihat bagaimana hasil dari tindakan yang telah dilakukan Petinggi Jepi dalam membangun desa Dempar. Ia telah melakukan hal-hal yang bermanfaat bagi kelestarian lingkungan Dempar, sehingga desa Dempar dapat dikenal sebagai desa yang berkembang dan memiliki masa depan yang baik di mata masyarakat dalam mau pun luar. Hal tersebut membuktikan bahwa Petinggi Jepi memiliki kepedulian yang besar terhadapmasa depan lingkungan desa Dempar.

"Tapi rencanamu sendiri? Begitu spektakuler..."

"Harus begitu. Kalau tidak, nanti semua kawasan di situ dijarah orang kota. Apalagi kalau mereka mengetahui potensi yang ada. Danau dan lahan di 
sekitarnya merupakan aset yang harus diselamatkan". (Hal. 47, paragraf 6)

Sikap kasih sayang dan kepedulian terhadap alam pada kutipan di atas ditunjukkan oleh sikap Nori yang dengan tegas meyakini ayahnya bahwa ide yang telah ia rancang harus betul-betul terlaksana. Karena dengan hal itulah ia dapat menyelamatkan aset-aset di sekitar Dempar agar tidak diambil alih oleh sembarangan orang. Sikap Nori tersebut menunjukkan sikap kepeduliannya terhadap alam, agar alam senantiasa terjaga dan terawat kelestariannya.

"Tapi tanah itu harus dilindungi", lelaki lainnya yang tadinya menjadi penonton ikut nimbrung juga. "Seperti lou kita ini. Lou ulu masih milik kita, meskipun tak ada penghuninya." (Hal. 107, paragraf 1)

Sikap kasih sayang dan kepedulian terhadap alam pada kutipan di atas ditunjukkan oleh kepedulian para warga desa Dempar yang tidak rela jika tanah sekitar desa dikapling seenaknya oleh perusahaan kota. Mereka berdiskusi untuk mencari solusi atas apa yang terjadi guna melindungi lingkungan mereka dari perusahaan-perusahaan luar yang ingin menyerobotnya.

\section{Sikap Tidak Mengganggu Kehidupan Alam}

Nilai toleransi ini berkaitan dengan kemampuan menghormati dan menjaga keberadaan dan keadaan alam disekitar untuk tidak merugikan alam secara tidak perlu dan membiarkan alam dalam keadaan tidak tersentuh. Sikap tidak mengganggu kehidupan alam ditunjukkan pada kutipan, sebagai berikut.

"Huma adalah penghasil padi dan palawija untuk semua warga lou. Setiap warga memiliki kawasan tertentu yang telah diperuntukkan menjadi kawasan huma. Tidak sembarang tempat dapat dijadikan huma." (Bab 5, hal. 31, baris ke 6)

Kutipan di atas merupakan sikap tidak mengganggu kehidupan alam, hal tersebut dapat dilihat dari apa yang dilakukan warga lou dalam menjadikan huma dengan cara yang tidak sembarangan. Mereka harus mengikuti arahan yang telah ada untuk tidak menjadikan sembarangan kawasan sebagai huma, karena mereka tahu ada kawasan tertentu yang memang telah diperuntukkan sebagai huma dan mereka dapat melakukannya.

"Tradisi telah menentukan bahwa kawasan hutan itu dibagi dalam enam macam peruntukan."

"Enam? Enam macam peruntukkan? Untuk...?"

"Untuk menentukan lokasi tertentu. Bagian mana yang boleh dirambah dan dijadikan ladang, bagian mana yang hanya boleh sebagai hutan persediaan." (Hal. 31, baris ke 8)

Kutipan di atas dapat dinilai sebagai telaah sikap tidak mengganggu kehidupan alam. Hal tersebut dapat dilihat pada peruntukkan yang telah ditentukkan dalam tradisi, bahwa masing-masing kawasan memiliki aturan yang perlu diterapkan untuk menentukan lokasi ladang. Bagian yang memang boleh dijadikan ladang warga dapat merambah tanah itu, sedangkan bagian yang hanya bisa dijadikan hutan persediaan para warga tidak boleh menjadikannya sebagai ladang mereka.

"Begini. Di kawasan lou berdiri, ada seluasan tanah yang dikhususkan untuk ditanam dengan buah-buahan tertentu, seperti lai, durian, langsat, nangka, encepm payakng, encepm bulau, keramuq, rambutan, cempedak, rekep, siwo, dan sebagainya. Kawasan itu merupakan hutan tetap yang tidak boleh dirambah siapa pun. Semua warga merupakan pemiliknya, meskipun pohon-pohon itu mungkin hanya 
ditanam oleh Petinggi atau salah seorang warga lou." (Hal. 31, baris ke 13)

Sikap tidak mengganggu kehidupan alam dapat dilihat dari kutipan di atas tentang aturan perambahan hutan yang tidak boleh dilakukan oleh siapa pun, sekalipun orang yang menanamnya. Karena mereka telah menjadikan kawasan tersebut hanya sebagai hutan tetap saja, meskipun hutan itu milik bersama, para warga sudah sepakat untuk tidak merambahnya.

"Kearifan itu membuat warga tidak sembarangan menebang atau menggali. Tapi orang-orang yang datang dari kota dengan rakusnya membabat hutan, mengambil pohon, menggali tambang, dan membuka tanah, membakar hutan hingga asap api menutupi langit." (Hal. 34 , paragraf 4)

Sikap tidak mengganggu kehidupan alam pada kutipan di atas ditunjukkan oleh warga desa Dempar yang memiliki sikap kearifan untuk tidak sembarangan menebang pohon atau pun menggali tanah di sekitar hutan secara tidak perlu. Akan tetapi sangat disayangkan sikap orang-orang kota yang semena-mena memperlakukan alam sudah diluar batasan dari hal-hal yang warga Dempar lakukan untuk selalu berusaha menjaga dan merawat alam di sekitar mereka sampai saat ini.

Hasil dalam penelitian ini berupa pendeskripsian tentang kearifan lingkungan yang dilakukan oleh para warga Desa Dempar dalam suku Dayak Benuaq. Kehidupan mereka masih sangat kental akan adat istiadat dan budayanya, serta memiliki kepedulian besar terhadap kondisi lingkungan alam di sekitarnya. Kehidupan yang masih sangat kental akan adat istiadat dan budayanya membuat mereka sangat menghargai akan peninggalanpeninggalan yang ditinggalkan dari nenek moyang terdahulu, serta kepedulian besar terhadap kondisi lingkungan alam di sekitar membuat mereka lebih peka terhadap lingungkan untuk selalu menjaga, melindungi, dan merawatnya.

Nilai yang terdapat dalam kearifan lingkungan merupakan nilai yang perlu diterapkan oleh manusia dalam pengelolaan dan pelestarian ekosistem/sumber daya alam di lingkungan sekitarnya. Sehingga manusia akan lebih paham dalam bagaimana menyikapi hal-hal yang dapat dilakukan kepada alam dengan memperlakukan alam dengan cara yang baik dan benar dalam menghormati alam sebagaimana mestinya. Hal ini sejalan dengan yang dikatakan oleh Harsono (2008) bahwa ekologi dapat diartikan sebagai kajian itmiah tentang pota hubungan-hubungan tumbuh-tumbuhan, hewan. hewan, dan manusia terhadap satu sama lain dan terhadap [ingkungantingkungannya. Kritik dapat diartikan sebagai bentuk dan ekspresi penitaian tentang kuatitas-kuatitas baik atau buruk dari sesuatu. Secara sederhana ekokritik dapat dipahami sebagai kritik benryawasan tingkungan.

Keadaan lingkungan dan alam mempunyai pengaruh besar terhadap kesastraan dan kebutuhan hidup manusia. Perubahan yang terjadi pada alam dan lingkungan (ekologis) tentunya akan membuat manusia menyesuaikan dengan gagasan dan pandangan mereka. Lingkungan yang mengelilingi sastrawan jelas akan menjadi tumpuan imajinatif (Darman, 2017).

Dari hasil analisis yang penulis temukan tentang kearifan lingkungan terdapat 5 nilai kearifan lingkungan dalam Endraswara (2016) yaitu (1) telaah sikap hormat terhadap alam yang dimiliki oleh para warga Dempar yang memperlakukan alam dengan cara yang baik dan benar. Misalnya melestarikan dan menjaga lahan-lahan palawija, perkebunan rotan, menghasilkan kualitas yang baik dan memiliki nilai ekonomi yang cukup tinggi (AAA (KLR) 2015); (2) sikap tanggung jawab moral terhadap alam yang dimiliki oleh para warga Dempar yang selalu taat terhadap aturan, tradisi, dan adat yang sudah diakui dan diterapkan dari nenek moyang terdahulu. 
Misalnya mereka akan dihukum dan menghukum siapa saja yang telah melanggar aturan tentang tata cara memperlakukan alam atau beretika dalam lingkup sosial baik disengaja maupun tidak (AAA (KLR) 2015); (3) sikap solidaritas terhadap alam yang dimiliki oleh Petinggi Jepi dan para warga yang merasakan keresahan terhadap kerusakan lingkungan yang terjadi karena ulah yang dilakukan oleh pengusaha $\mathrm{HPH}$ dan HTI atas kebakaran hutan yang terjadi. Hal tersebut sangat disayangkan oleh warga, mengingat bahwa para warga Dempar memandang tanah, akar, pohon, dan daun memiliki jiwa seperti mereka, sehingga mereka Akan sangat berhati-hati dan penuh ketelatenan dalam merawat dan menjaganya (AAA (KLR) 2015); (4) kasih sayang dan kepedulian terhadap alam yang dimiliki oleh Petinggi Jepi atas upayanya dalam membangun desa Dempar yang hingga kini telah mencapai usia dua puluh tahun, tetapi sudah menampakan tandatanda perkembangan yang baik untuk masa depan. Sikap kepedulian juga dimiliki oleh anaknya, Nori, dalam merancang ide-ide yang akan membuat kawasan-kawasan yang tidak terawat menjadi kawasan yang memiliki potensi besar untuk warga Dempar. Selain itu, sikap para warga pun menunjukkan bahwa kepedulian merupakan hal terpenting dalam melindungi lingkungan agar tidak gampang dijajah oleh orang asing (AAA (KLR) 2015); (5) sikap tidak mengganggu kehidupan alam yang dimiliki oleh para warga Dempar yang selalu taat pada aturan untuk tidak semena-mena memperlakukan alam, misalnya telah ada aturan dan tata cara tertentu dalam menentukan kawasan hutan yang telah dibagi kawasan mana yang boleh untuk dijadikan huma dan kawasan mana yang tidak boleh dijadikan huma (AAA (KLR) 2015).

\section{KESIMPULAN}

Berdasarkan hasil penelitian dan pembahasan dapat disimpulkan bahwa kearifan lingkungan yang terdapat dalam novel Api Awan Asap karya Korrie Layun Rampan terdiri atas nilai a) telaah sikap hormat terhadap alam, b) sikap tanggung jawab terhadap alam, c) sikap solidaritas terhadap alam, d) sikap kasih sayang dan kepedulian terhadap alam, dan e) sikap tidak mengganggu kehidupan alam. Kearifan lingkungan tersebut disajikan dengan memperlihatkan bagaimana sikap para warga desa Dempar dalam merawat, menjaga, dan melestarikan lingkungan di sekitar desa Dempar.

\section{REFERENSI}

Darman, F. (2017). Representasi Manusia dan Alam dalam Puisi Aku, Hutan Jati, dan Indonesia Karya Yacinta Kurniasih. Totobuang. Vol. 5. No.2.

Dewi, N. (2015). Manusia dan Lingkungan dalam Cerpen Indonesia Kontemporer: Analisis Ekokritik Cerpen Pilihan Kompas. Litera. 14(2): 377.

Endraswara, S. (2016). Metodologi Penelitian: Ekologi Sastra. Yogyakarta: CAPS.

Erliansyah, A. (2019). "Analisis Novel Api Awan Asap Karya Korrie Layun Rampan dengan Pendekatan Ekokritik." Skripsi. Universitas Muhammadiyah Sumatera Utara.

Görlin, H. (2009). Från ekologi till ekokritik:en skiss over ekokritikens framväxt. Litteratur Och Språk. 5: 5.

Harsono, S. (2008). Ekokrtitik: Kritik Sastra Berwawasan Lingkungan. Kajian Sastra. Vol. 32. No 1.

Hetti, R. (2015). Local Wisdom dan Perilaku Ekologis Masyarakat Dayak Benuaq. Indigenous. 13 (1)

Iskandar, J. (2001). Manusia, Budaya, dan Lingkungan: Kajian Ekologi Manusia. Bandung: Humaniora Utama Press 
Juanda. (2018). Fenomena Eksploitasi Lingkungan dalam Cerpen Koran Minggu Indonesia Pendekatan Ekokritik. Aksis. 2(2): 170.

Juliasih. (2012). Manusia dan Lingkungan dalam Novel Life in The Iron Mills Karya Rebecca Hardings Davis. Litera. Vol 11.

Miles, M. B. \& Huberman, A., M. (2007). Analisis Data Kualitatif. Jakarta: Universitas Indonesia Press.

Rampan, K. L. (2015). Api Awan Asap. Jakarta: Grasindo.

Rosyidah, U. N. D. (2013). Sketsa Karya Ari Nur Utami: Arsitektur Urban dalam Perspetif Ekokritisisme. Atavisme. Vol $\underline{16, \text { No } 2}$

Setiawan, F N. dkk. (2018). Manifestasi Kearifan Ekologis dalam Karo dan Kasada: Sebuah Perspektif Ekokritik. Atavisme. 21(2): 210.

Sukmawan, S. (2016). Ekokritik Sastra. Malang: UB Press. 